ZOOLOGIA 29 (5): 483-487, October, 2012

doi: $10.1590 /$ S1984-46702012000500014

\title{
Placoscopana, a new genus of Neocoelidiinae (Hemiptera: Cicadellidae) from Ecuador
}

\author{
Clayton Correa Gonçalves ${ }^{1}$, Ana Paula Marques-Costa ${ }^{2} \&$ Rosaly Ale-Rocha ${ }^{1}$
}

\author{
${ }^{1}$ Coordenação de Pesquisas em Entomologia, Instituto Nacional de Pesquisas da Amazônia. Caixa Postal 478, 69011-970 \\ Manaus, AM, Brazil.E-mail: clayton.correa.goncalves@gmail.com; alerocha@inpa.gov.br \\ ${ }^{2}$ Departamento de Biologia, Universidade Federal de Sergipe. Avenida Marechal Rondon, Jardim Rosa Elze, 49100-000 São \\ Cristóvão, SE, Brazil. E-mail: apmc@ufs.br
}

\begin{abstract}
A new genus of Neocoelidiinae, Placoscopana gen. nov. is proposed and its type-species Placoscopana nigrilinea sp. nov. is described and illustrated based on a male specimen from Ecuador (Orellana Province). Placoscopana gen. nov. is very similar externally to Coronalidia Marques-Costa \& Cavichioli, 2007, but differs mainly by the male genitalia: pygopher short with posterior margin approximately truncated; subgenital plates, in dorsal view, with a tuft of setae at apex; and aedeagus with two parallel ventral rows of small spines on the apical half of the shaft.
\end{abstract}

KEY WORDS. Leafhoppers; Neotropical Region; new species; taxonomy.

Neocoelidiinae includes leafhoppers restricted to the New World, and most of its species are endemic to the Neotropical Region (Nielson \& KNIGHT 2000). The subfamily has 173 valid species in 32 genera (Marques-Costa 2011, Gonçalves et al. 2011, 2012).

The leafhoppers of this subfamily are small to large (3.0$14.0 \mathrm{~mm}$ ), with the general color showing mainly pale tones, and can be identified by the following characteristics: 1) crown usually elevated and flat between the eyes; 2 ) ocelli on or near the anterior margin of the head; 3 ) antennae exceptionally long, frequently exceeding the entire length of the body, including the forewings at rest; 4) mesothorax frequently well developed, pleurae extending to the sternum, giving individuals a swollen aspect ventrally; 5) forewings with venation usually indistinct, except apically; 6) transverse vein $\mathrm{r}-\mathrm{m}_{1}$ of the forewings $\mathrm{ab}$ sent; 7) $\mathrm{R}_{4+5}$ and $\mathrm{M}_{1+2}$ of the hindwings usually confluent preapically, fused at the apex, forming a single vein; 8) femoral formula of the hindlegs usually $2+2+1$; and 9) valve of the male genitalia generally entirely fused to the subgenital plates (KRAMER 1964, Dietrich 2003). The present contribution describes a new genus, Placoscopana gen. nov., and a new species Placoscopana nigrilinea sp. nov. from Ecuador.

\section{MATERIAL AND METHODS}

The abdomen was removed and placed in hot $10 \% \mathrm{KOH}$, following OMAN (1949) but with a slightly shorter heating time (about 3-5 minutes). Softened genitalia were washed for 5-10 minutes in hot water and placed on a concave slide with glycerin to be photographed. The genitalia were then stored in plastic microvials with glycerin, and pinned together with the specimen. Digital photographs were taken with a Leica DFC295 camera coupled to a stereomicroscope, combined with Automontage software.

The terminology in the descriptions follows primarily Kramer (1964) and Young $(1968,1977,1986)$, except for terms of the head structures, which follow HamiLton (1981); the wing venation, which follows Сомsтоск \& Neеdнам $(1898,1899)$ and OMAn (1949); and hindleg chaetotaxy, which follows RaKitov (1998).

\section{TAXONOMY}

\section{Placoscopana gen. nov.}

Type-species. Placoscopana nigrilinea sp. nov.

Diagnosis. Crown subpentagonal with lateral margins sinuate; coronal suture evident on basal two-thirds, extending to near anterior margin of crown (Fig. 1); with carina separating face and crown (Figs 1-3); apex of maxillary plates exceeding apical margin of clypeus (Fig. 2); ocelli small, on anterior margin of head, between crown and frons, closer to eyes than to midline; posterior margin of pronotum emarginate and inverted V-shaped (Fig. 1); forewings with venation slightly distinct, more distinct in apical portion, with four apical cells and three anteapical cells (Fig. 4); hindwings with $\mathrm{R}_{4+5}$ and $\mathrm{M}_{1+2}$ preapically convergent, fused at apex, forming single vein; male pygofer short, posterior margin approximately truncate, with ventral process; anal tube without processes (Fig. 5); subgenital plates fused on basal portion, dorsal surface with tooth and tuft of setae at apex (Figs 6-7); connective Y-shaped (Fig. 9); aedeagus simple, without processes, with two parallel ventral rows of small spines on apical half of shaft (Fig. 11). 
Description. Head, in dorsal view, with crown approximately pentagonal, slightly produced beyond compound eyes, wider than long, crown median length about three-fourths of interocular width and two-fifths of transocular width; crown slightly concave on posterior portion around the distinct coronal maculae; coronal suture evident on basal two-thirds of crown, extending to near anterior margin of crown; anterior margin of crown slightly angled and carinate; lateral margins, adjacent to compound eyes, sinuate and carinate; posterior margin arched (Fig. 1); small ocelli on anterior margin of head between crown and frons, closer to eyes than to midline, visible in dorsal and lateral views; antennae very long, exceeding half length of forewing (Fig. 12); in lateral view, antennal ledges oblique and carinate (Fig. 3); antennal pits at same level as a line tangent to anteroventral angles of eyes; in frontal view, frons approximately 1.5 times longer than its basal width, with texture finely punctuated, and muscle impressions slightly distinct near lateral margins; in lateral view, frons slightly convex, not swollen or carinate on base (portion between compound eyes); frontogenal sutures reaching ocelli; lora halfmoon-shaped, apical margin not reaching apex of clypeus; genae incompletely covering episternum, the latter with apex visible; epistomal suture distinct, complete and straight; apex of maxillary plates exceeding apical margin of clypeus; clypeus rectangular with parallel lateral margins (Fig. 2); in lateral view, clypeus with slight apical gibbosity (Fig. 3).

Thorax. Pronotum wider than head, width between humeri approximately one-fifth greater than transocular width; lateral margins rounded, posterior margin emarginate and inverted V-shaped, surface with slight horizontal striations (Fig. 1); dorsopleural carina complete (Fig. 3); in ventral view, mesothorax moderately swollen; mesonotum smooth, as long as wide, preapical groove distinct (Fig. 1); forewing about 3.5 times longer than its maximum width, apex rounded, without pits; venation slightly distinct, more distinct apically; four apical cells, all approximately rectangular (Fig. 4); base of second apical cell more proximal than bases of third and fourth cells and base of fourth more proximal than third cell; three anteapical cells, only outer cell closed basally; narrow appendix, restricted to first apical cell; hindwings with $\mathrm{R}_{4+5}$ and $\mathrm{M}_{1+2}$ preapically convergent, fused at apex, forming single vein. Hindleg with femoral setal formula 2+2+1; PD setal tibial row with long, thick and separated setae, with 1-4 intercalary long slender setae only on apical third; AD row with long spiniform setae, with bases prominent, thicker than those of PD row, and with two or more intercalary microsetae distributed along entire length of tibia; AV row with long slender setae, absent on proximal fourth and well separated on distal fourth, intercalary setae absent; PV row densely bristled, with short fine setae at base, progressively lengthening towards apex, setae distributed along entire length of tibia; first tarsomere as long as combined length of two distal tarsomeres, plantar surface with two parallel rows of microsetae.
Male genitalia. Pygofer short, posterior margin approximately truncate and with ventral process; anal tube without processes (Fig. 5); valve entirely fused to subgenital plates; subgenital plates fused on basal portion, dorsal surface with tooth and tuft of setae at apex (Figs 6-7); styles simple, without preapical lobe, lateral margins smooth, without irregularities or undulations, apex sclerotized and sharp, strongly curved ventrally, apical third with setae (Figs 8-9); connective Y-shaped, not bifurcate at articulation point with aedeagus (Fig. 9); aedeagus simple, anterodorsally curved, without processes, with two parallel ventral rows of small spines on apical half of shaft (Fig. 11).

Geographical distribution. Ecuador.

Etymology. The generic name is feminine, and combines the Greek prefix placo-, which means plaque or plate, with scopa, which means broom, and the suffix -ana, common in names of other Neocoelidiinae genera. The name refers to the subgenital plates of the male genitalia, which bear a tuft of setae at the apex of the dorsal surface, a characteristic not present in any other genus of the subfamily.

Remarks. Placoscopana gen. nov. is externally very similar to Coronalidia Marques-Costa \& Cavichioli, 2007, but the male genitalic characters are quite different. In Coronalidia the pygofer has the apical third narrowed and sharp, bifurcated or not, a ventral medium tooth and a pair of internal preapical lobes covered by denticles; the anal tube has a basal single process, with variable shape; the subgenital plates are fused throughout their length except on the apical portion, without a tuft of setae apically on the dorsal surface; and the aedeagus is basally stout, with a pair of preapical lateral processes and with ventral margin covered by denticles at middle third.

\section{Placoscopana nigrilinea sp. nov. Figs 1-14}

Diagnosis. Forewings with inner margin of clavus blackened; pygofer trapezoidal, with posterior margin approximately truncate, with numerous apical setae and claw-like ventroapical process (Fig, 5); connective with about half length of style (Fig. 9); aedeagus with one pair of dorsoapical lamellae (Fig. 10).

Description. External morphological characters as in generic description.

Measurements (mm). Male holotype: total length 8.8; crown median length 0.65 ; transocular width 1.74 ; interocular width 0.91 ; frons basal width 0.77 ; frons median length 1.15 ; pronotum median length 0.83 ; width between humeri 2.17 ; mesonotum median length 1.44 ; mesonotum maximum width 1.52; forewing length 7.04; forewing maximum width 2.0.

Color (Figs 12-13). General color ivory. Mesonotum with two lateral subtriangular gray spots. Forewing semi-opaque ivory on basal two-thirds, and semi-hyaline brown on apical third; inner margin of clavus blackened. Hindwing hyaline with ivory venation. Legs pale yellow.

Male genitalia (Fig. 14). Pygofer, in lateral view, trapezoidal and short, enlarged basally, gradually narrowed towards 

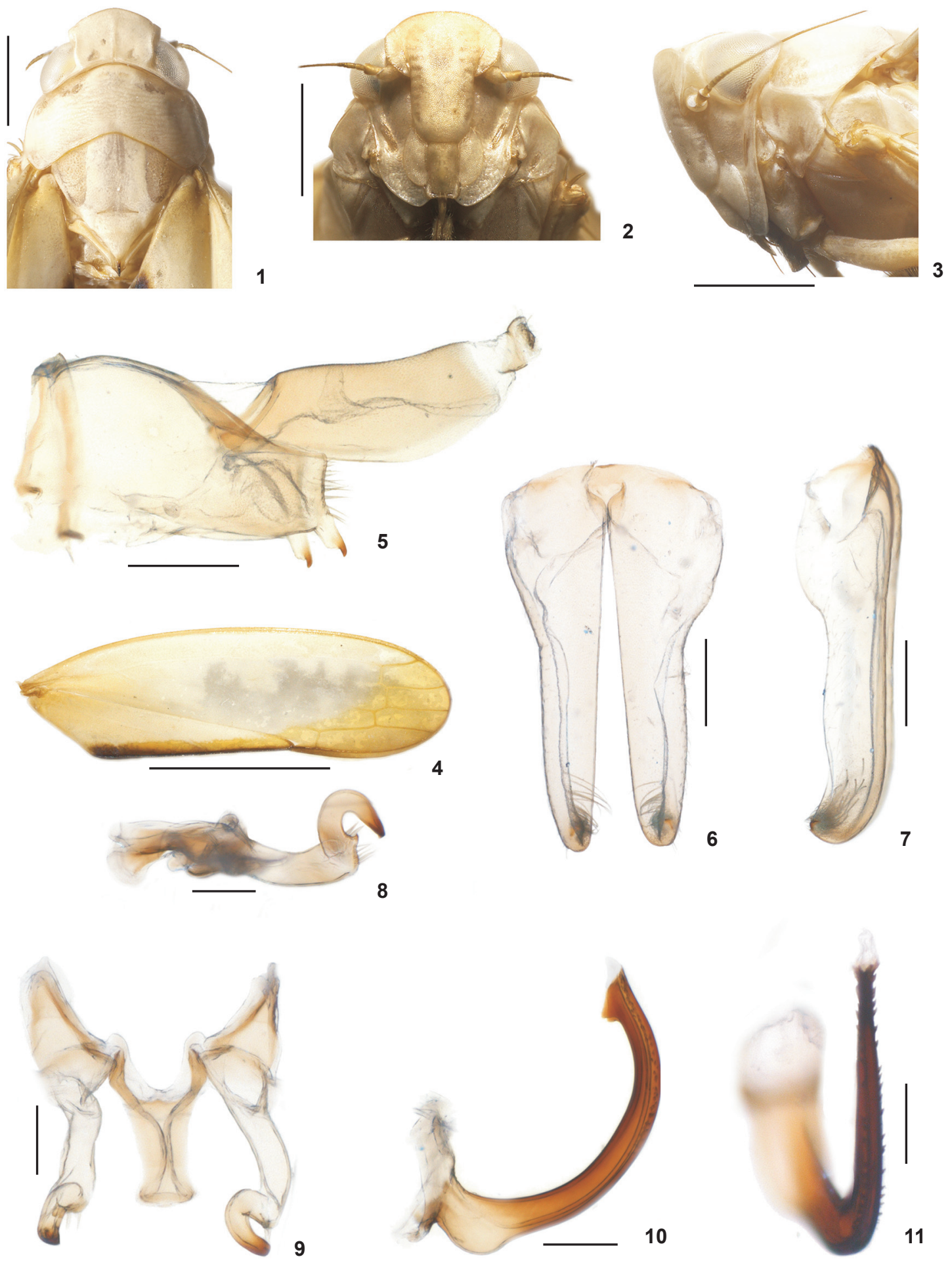

Figures 1-11. Placoscopana nigrilinea sp. nov., male holotype: (1) head, pronotum, mesonotum, and base of wings, dorsal view; (2) head, frontal view; (3) head, pronotum, mesonotum, and base of wings, lateral view; (4) forewing; (5) pygofer and anal tube, lateral view; (6) valve and subgenital plates, ventral view; (7) valve and subgenital plates, lateral view; (8) style, lateral view; (9) connective and styles, dorsal view; (10) aedeagus, lateral view; (11) aedeagus, posterior view. Scale bars: 1-3=1.0 mm, $4=2.0 \mathrm{~mm}, 5-7=0.5 \mathrm{~mm}, 8-11=0.2 \mathrm{~mm}$. 

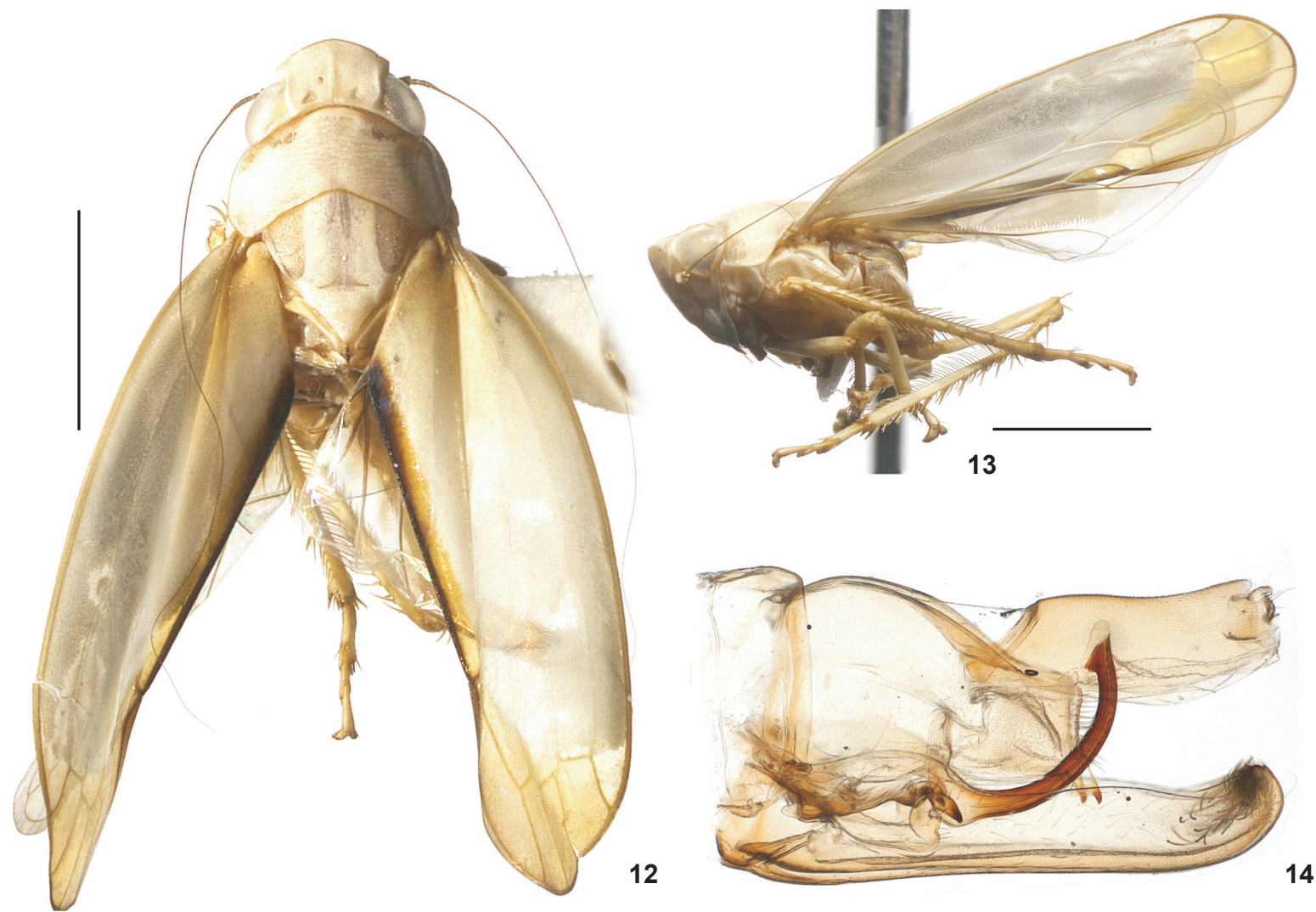

Figures 12-14. Placoscopana nigrilinea sp. nov., male holotype: (12) dorsal view; (13) lateral view; (14) male genitalia, lateral view. Scale bars: $12=1.0 \mathrm{~mm}, 13=2.0 \mathrm{~mm}, 14=0.5 \mathrm{~mm}$.

apex; posterior margin approximately truncated, with numerous apical setae and claw-like sclerotized ventroapical process (Fig. 5). Anal tube enlarged, without process (Fig. 5). Subgenital plates almost twice longer than pygofer, fused only in basal sixth; in ventral view, approximately triangular, narrowed towards apex, with rounded apices; numerous short delicate setae present on outer margin; apical portion with tuft of setae of variable size on inner dorsal surface (Fig. 6); in lateral view, enlarged on basal third, and with apical dorsal sclerotized tooth (Fig. 7). Styles short, approximately one-third length of subgenital plates; in lateral view, with sclerotized apical third, strongly curved ventrally, with small sclerotized tooth and numerous setae on ventral surface of preapical region (Fig. 8); in dorsal view, basal region enlarged, subtriangular (Fig. 9). Connective, in dorsal view, Y-shaped; about half length of style; not bifurcate at articulation point with aedeagus (Fig. 9). Aedeagus sclerotized; in lateral view, slender and anterodorsally curved; atrium region slightly enlarged; with one pair of dorsoapical subtriangular lamellae; preatrium very short, approximately one-third length of dorsal apodeme; gonopore apical (Fig. 11); in posterior view, with two parallel rows of small spines on ventral apical half of shaft (Fig. 10).
Female unknown.

Specimen examined. Male holotype (USNM), with following labels: "Ecuador: Orellana, Tran- \sect Ent. $1 \mathrm{~km} \mathrm{~S}$ Onkonegare $\backslash$ Camp. Reserva Etnica Waorani $\backslash 00^{\circ} 39^{\prime} 10^{\prime} \mathrm{S}$, $076^{\circ} 26^{\prime} 00^{\prime \prime} \mathrm{W}$; 22-Jun-96 T.L. Erwin et al $\backslash$ Fogging terra firme forest $\backslash$ Lot\#1574".

Geographical distribution. Ecuador (Orellana Province).

Holotype condition. Thorax ventrally glued to a triangle by left side; antennae and legs entire; left forewing broken from the costal margin to the center of the outer preapical cell; right forewing broken on the third and fourth apical cells.

Etymology. From Latin, nigri $=$ black, dark, and linea $=$ line, referring to the color of the forewing with the inner margin of the clavus blackened.

\section{ACKNOWLEDGMENTS}

We are grateful to Thomas Henry, Stuart McKamey, Terry L. Erwin, and David G. Furth for the loan of material for study; to the Insect Systematics Laboratory of the Instituto Nacional de Pesquisas da Amazônia, for access to Automontage software; and to the Coordenação de Aperfeiçoamento de Pessoal de Nível Superior (CAPES) for financial support. 


\section{LITERATURE CITED}

Comstock, J.H. \& J.G. Needham. 1898. The wings of insects. American Naturalist 32: 43-48, 81-89, 231-257, 335-340, 413-424, 561-565, 768-777, 903-911.

Comstock, J.H. \& J.G. Needham. 1899. The wings of insects. American Naturalist 33: 117-126, 573-582, 845-860.

Dietrich, C.H. 2003. Some unusual Neotropical Neocoelidiinae with a redefinition of the subfamily (Hemiptera: Membracoidea: Cicadellidae). Annals of the Entomological Society of America 96 (6): 700-715.

Gonçalves, C.C.; A.P. Marques-Costa \& R. Ale-Rocha. 2011. A new species of Tetralidia Marques-Costa \& Cavichioli (Hemiptera: Cicadellidae: Neocoelidiinae) from Amazon Region. Zootaxa 3070: 23-28.

Gonçalves, C.C.; A.P. Marques-Costa \& R. Ale-Rocha. 2012. Coelindroma Kramer (Hemiptera: Cicadellidae: Neocoelidiinae) from Brazil: description of two new species and new record of C. fungosa. Zootaxa 3349: 40-47.

Hamilton, K.G.A. 1981. Morphology and evolution of the rhynchotan head (Insecta: Hemiptera, Homoptera). Canadian Entomologist 113: 953-974.

Kramer, J.P. 1964. A generic revision of the leafhopper subfamily Neocoelidiinae. (Homoptera: Cicadellidae). Proceedings of the United States National Museum 15: 259-287.

Marques-Costa, A.P. 2011. Aglaenita (Hemiptera: Cicadellidae: Neocoelidiinae): a new species from Brazil. Zoologia 28 (1): 122-126.

Nielson, M.W. \& W.J. Knight. 2000. Distributional patterns and possible origin of leafhoppers (Homoptera, Cicadellidae). Revista Brasileira de Zoologia 17: 81-156.

Oman, P.W. 1949. The Nearctic leafhoppers (Homoptera: Cicadellidae). A generic classification and check list. Memoirs of the Entomological Society of Washington 3: $1-253$.

Rakitov, R.A. 1998. On differentiation of cicadellid leg chaetotaxy. Russian Entomological Journal 6: 7-27.

Young, D.A. 1968. Taxonomic study of the Cicadellinae (Homoptera, Cicadellidae). Part 1. Proconiini. Bulletin of the United States National Museum 261: 1-287.

Young, D.A. 1977. Taxonomic study of the Cicadellinae (Homoptera: Cicadellidae) Part 2. New World Cicadellini and genus Cicadella. Bulletin of the North Carolina Agricultural Experiment Station 239: VI+1135 p.

YounG, D.A. 1986. Taxonomic study of the Cicadellinae (Homoptera: Cicadellidae) Part 3. Old World Cicadellini. Bulletin of the North Carolina Agricultural Experiment Station 281: 1-639.

Submitted: 25.IV.2012; Accepted: 18.VII.2012.

Editorial responsibility: Gabriel L.F. Mejdalani 